\title{
Preparation of Thermal Insulation Plaster with FGD Gypsum
}

DOI: 10.15255/KUI.2016.006

KUI-20/2016

Professional paper

Received February 17, 2016

Accepted April 29, 2016

\author{
Y.-C. Zhang, ${ }^{a}$ S.-B. Dai, ${ }^{a}$ J. Huang, ${ }^{{ }^{*}}$ S.-G. Duan, ${ }^{a}$ and Z.-Z. Zhi ${ }^{\mathrm{b}}$ \\ a School of Civil Engineering and Architecture, Wuhan University of Technology, \\ Wuhan 430 070, P. R. China \\ bSchool of Materials Science and Engineering, Wuhan University of Technology, \\ Wuhan 430 070, P. R. China
}

\begin{abstract}
\| Abstract
Thermal insulation gypsum plaster was prepared from flue gas desulphurization (FGD) gypsum. K12 is more recommendable as foaming agent, when the mass fraction of K12 is around $0.1 \%$, the setting time and compressive strength meet the requirements of gypsum-based construction materials. In the meanwhile, the thermal conductivity is $0.18 \mathrm{~W} \mathrm{~m}^{-1} \mathrm{~K}^{-1}$, which can be used as a thermal insulation material. The hemihydrate mixtures obtained, allow the design of a new wall structure, which is more efficient as a thermal insulation system. The wall heat transfer coefficient test was carried out to compare thermal performance of two different thermal insulation systems. Compared with the thermal performance of a conventional system, the heat transfer coefficient of the new system was reduced by $5.6 \%$. Finally, energy-saving analysis of a building was carried out to compare the energy-saving effect of the conventional and new systems of building. The energy-savings of the building with the new system increased by almost $2 \%$, thus resulting in low energy consumption of the building.
\end{abstract}

$\|$ Keywords

FGD gypsum, heat insulation system, heat transfer coefficient, foaming agent, energy efficiency

\section{Introduction}

The emission of $\mathrm{SO}_{2}$ is about $20 \cdot 10^{6}$ tons per year in China, of which about $50 \%$ is generated from power plants. Acid rain caused by $\mathrm{SO}_{2}$ leads to the pollution of the environment. To date, wet desulphurization technology has been used to precipitate the generated $\mathrm{SO}_{2}$ from power plants. The limestone/lime-gypsum wet flue gas desulphurization process employs limestone/lime as an absorbent. Calcium in the limestone/lime absorbent reacts with the $\mathrm{SO}_{2}$ existing in the boiler gases so that $\mathrm{CaSO}_{4} \cdot 2 \mathrm{H}_{2} \mathrm{O}$ is formed in the spray absorber tower. Nonetheless, this method generates large amounts of FGD gypsum. This industrial by-product requires a large number of land resources, and causes serious environmental pollution if not treated properly. Calcined gypsum can be produced from waste FGD gypsum by its dehydration, which can be used as a building material. However, the utilization of FGD gypsum is insufficient considering the amount of its production. Calcined gypsum can be regarded as a green cement due to the considerable low costs and emissions during its manufacture in comparison with Portland cement. The mechanical properties of the hemihydrate from calcination of FGD gypsum, such as compressive strength, tensile strength, flexural strength, Young's modulus, and Poisson constant

* Corresponding author: Jun Huang

e-mail: lunwenww@sina.com have been measured ${ }^{1-2}$, as have the thermal properties of the hemihydrate. ${ }^{3-6}$ New composites based on gypsum matrix and mineral additives have been prepared in the research. ${ }^{4-13}$ However, with the improvement of the demand of building thermal environment, a gypsum plaster with an efficient thermal insulation function needed to be prepared. At present, there is little literature related to the preparation of thermal insulation gypsum plaster (TIGP).

In the preliminary study, the gypsum plaster for finish coating was prepared by adding a protein-based retarder (SC), a polycarboxylate-based water-reducing admixture (F10), and an ether-based water-retaining admixture (HPMC) to the hemihydrate from calcination of FGD gypsum. The initial setting time was 63 minutes, and the final setting time was 70 minutes, while the compressive strength was 11.5 MPa, which meets the requirements of the corresponding standard. The mass fractions of SC, F10, and HPMC was $0.25 \%, 0.5 \%$ and $0.1 \%$, respectively. ${ }^{14}$

Based on the preliminary study, thermal insulation gypsum plaster was prepared. The thermal performance and energy-saving impact of the new wall insulation system with thermal insulation gypsum plaster has been analysed. Overall, the work can be classified under the framework of applying innovative materials on wall thermal insulation systems. This paper is considered important for China, where energy consumption is continuously increasing in the hot-summer and cold-winter zone. 


\section{Experimental}

\subsection{Materials}

The material is the hemihydrate from calcination of FGD gypsum. The chemical composition of the hemihydrate is shown in Table 1, and the physical properties of the hemihydrate are shown in Table 2. The hemihydrate is produced by heating FGD gypsum to about $150{ }^{\circ} \mathrm{C}$ :

$$
\mathrm{CaSO}_{4} \cdot 2 \mathrm{H}_{2} \mathrm{O} \stackrel{\Delta}{\longrightarrow} \mathrm{CaSO}_{4} \cdot 1 / 2 \mathrm{H}_{2} \mathrm{O}+3 / 2 \mathrm{H}_{2} \mathrm{O}
$$

The plaster starts as a dry powder which is mixed with water to form a paste that liberates heat and then hardens. The plaster can be easily manipulated with metal tools after setting. Its characteristics make it suitable for a finishing, rather than a load-bearing material.

Table 1 - Chemical composition of the hemihydrate from calcination of FGD gypsum

Tablica 1 -Kemijski sastav hemihidrata nastalih kalcinacijom FGD gipsa

\begin{tabular}{c|c}
\hline $\begin{array}{c}\text { Components } \\
\text { Sastojci }\end{array}$ & $w / \%$ \\
\hline $\mathrm{CaO}$ & 32.79 \\
$\mathrm{SO}_{3}$ & 42.57 \\
$\mathrm{MgO}$ & 0.38 \\
$\mathrm{Al}_{2} \mathrm{O}_{3}$ & 0.33 \\
$\mathrm{SiO}_{2}$ & 1.79 \\
$\mathrm{Fe}_{2} \mathrm{O}_{3}$ & 0.14 \\
$\mathrm{SrO}$ & 0.05 \\
$\mathrm{Cl}$ & 0.02 \\
$\mathrm{~K}_{2} \mathrm{O}$ & 0.04 \\
\hline Ignition loss & 21.9 \\
\hline
\end{tabular}

Table 2 - Physical properties of the hemihydrate from calcination of FGD gypsum

Tablica 2 - Fizikalna svojstva hemihidrata nastalog kalcinacijom FGD-gipsa

\begin{tabular}{l|c|c}
\hline \multicolumn{2}{|l|}{$\begin{array}{l}\text { Fineness (mass fraction of particles }<80 \mu \mathrm{m} \text { ) } \\
\text { Finoća (maseni udjel čestica }<80 \mu \mathrm{m})\end{array}$} & $80 \%$ \\
\hline $\begin{array}{l}\text { Mass ratio water/gypsum } \\
\text { Maseni omjer vode i gipsa }\end{array}$ & $0.62: 1$ \\
\hline $\begin{array}{l}\text { Setting time/min } \\
\text { Vrijeme vezivanja/min }\end{array}$ & initial / početno & 4.5 \\
\hline Compressive strength/MPa & $24 \mathrm{~h}$ & 8.0 \\
\hline Tlačna čvrstoća/MPa & dry / suh & 17.4 \\
\hline $\begin{array}{l}\text { Flexural strength/MPa } \\
\text { Savojna čvrstoća/MPa }\end{array}$ & $24 \mathrm{~h}$ & 3.6 \\
\hline
\end{tabular}

SC, F10, and HPMC were firstly added to the hemihydrate to prepare the common gypsum plaster based on the preliminary study. Secondly, in order to prepare thermal insulation gypsum plaster, rosin $\left(\mathrm{C}_{19} \mathrm{H}_{29} \mathrm{COOH}\right)$ and sodium lauryl sulphate (K12) were adopted as foaming agents, respectively.

\subsection{Methods and equipment}

The samples with different foaming agent were filled in $40 \times 40 \times 40 \mathrm{~mm}$ modules, and dried at $40 \pm 2{ }^{\circ} \mathrm{C}$ in a muffle oven. Subsequently, the samples were cooled to room temperature.

Setting time: The setting time was tested in accordance with the Chinese standard GB/T 17669.4-1999. ${ }^{15}$ The time interval of test was $5 \mathrm{~min}$.

Compressive strength: The compressive strength was tested by a TYE-300 test device. The loading speed was $1.0 \mathrm{kN} \mathrm{s}^{-1}$. The strength development was determined in accordance with the Chinese standard JC/T 517-2004. ${ }^{16}$

Morphology: The morphology was observed by a scanning electron microscope (Quanta SEM 450). Firstly, sample powder was sprinkled on the double-sided tape. Secondly, silver powder was sprayed on the tape prior to observation.

Wall heat transfer coefficient: The test wall was placed between a hot chamber and a cold chamber to measure the air temperature, surface temperature, and power input to the hot chamber in the steady state. The heat transfer property of the test wall was calculated by the data. The wall heat transfer coefficient was determined in accordance with the Chinese standard GB/T 13475-2008. ${ }^{17}$

Energy-saving analysis: The heat transfer capacity of a building envelope was calculated using the reaction coefficient method by PBECA software. Internal surface temperature, external surface temperature, and heat flux in response to temperature disturbance of a triangular wave was calculated. Then, the reaction coefficient of the endothermic, exothermic, and transitive process was calculated. Finally, according to the temperature and heat flow calculated, the energy consumption and energy-saving efficiency of the building could be analysed.

\section{Results and discussion}

\subsection{Setting time}

The influence of the two foaming agents with different mass fractions on final setting time of the gypsum plaster is shown in Fig. 1. It can be observed that K12 has better retarding effect on the hemihydrate. When the mass fraction of $\mathrm{K} 12$ was $0.1 \%$, the final setting time was 83 min $(\leq 8 \mathrm{~h})$, which meets the requirements of gypsum-based construction materials. 


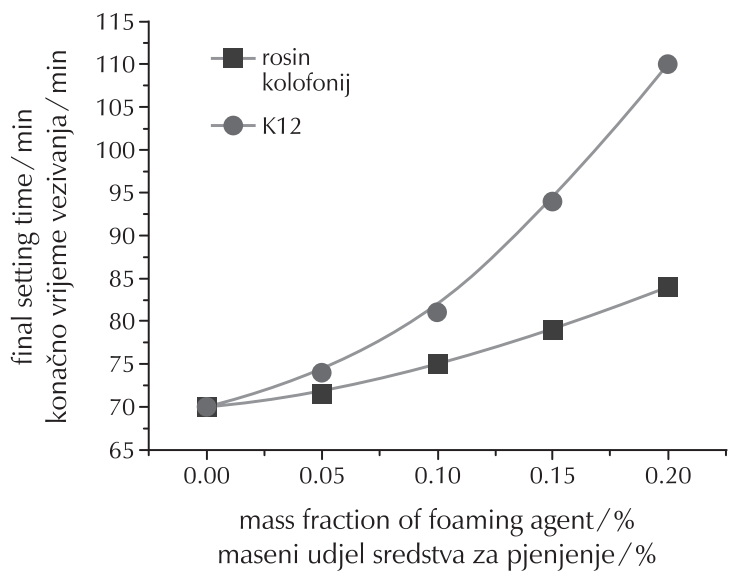

Fig. 1 - Final setting times of gypsum plaster with the addition of rosin and K12

Slika 1 - Konačno vrijeme vezivanja gipsane žbuke uz dodatak kolofonija i K12

\subsection{Compressive strengths}

Fig. 2 shows the influence of the two foaming agents on the compressive strength of gypsum plaster. It can be observed that the strength of the resulting gypsum decreases when the foaming agent is added. With more foaming agent, the acquired strength is lower. In addition, the extent of the compressive strength decline is relatively small when K12 is added as the foaming agent, which further proved that K12 was more suitable as foaming agent. When the mass fraction of $\mathrm{K} 12$ was $0.1 \%$, the compressive strength was $7.2 \mathrm{MPa}(\geq 6 \mathrm{MPa})$, which meets the requirement of building walls.

Fig. 3 presents the microstructure of gypsum plaster when K12 is added as foaming agent. The figure shows obvious generation of porosity. Therefore, the reason for the decrease in compressive strength is further explained from the microscopic point of view.

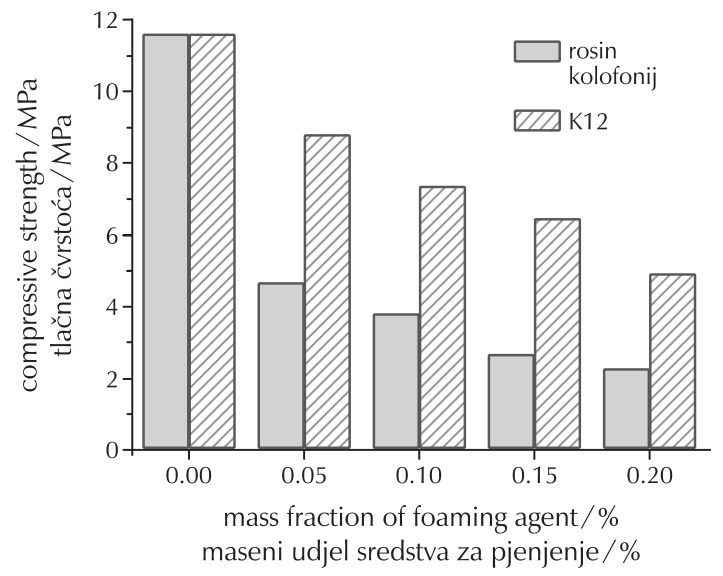

Fig. 2 - Compressive strengths of gypsum plaster with the addition of rosin and K12

Slika 2 - Tlačna čvrstoća gipsane žbuke uz dodatak kolofonija i K12

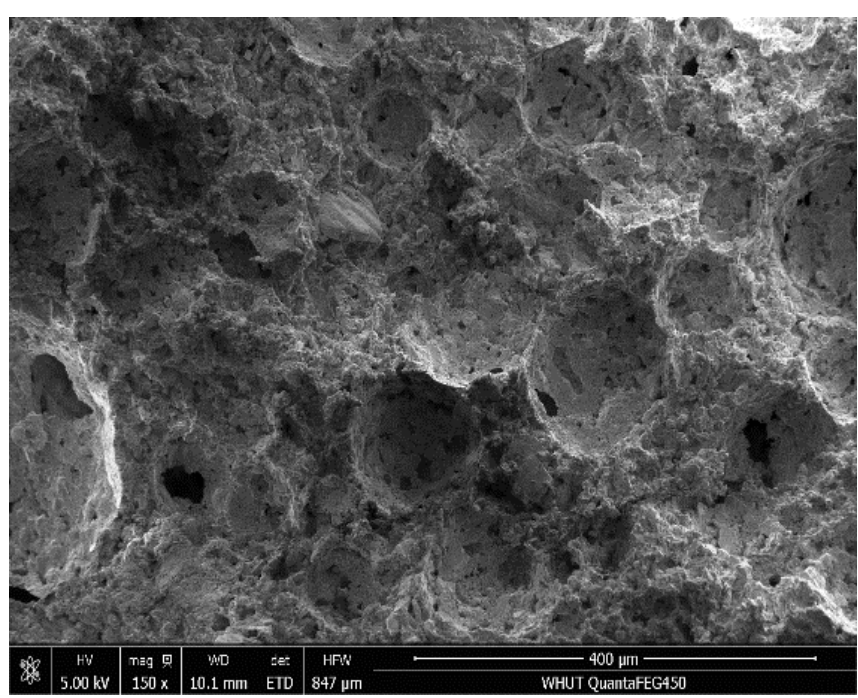

Fig. 3 - Microstructure of gypsum plaster with the addition of K12

Slika 3 - Mikrostruktura gipsa uz dodatak K12

\subsection{Thermal conductivity}

The thermal conductivity coefficient of insulation material is usually lower than $0.2 \mathrm{~W} \mathrm{~m}^{-1} \mathrm{~K}^{-1}$. This is an important index for evaluation of the thermal performance of a material. The thermal conductivity coefficients of gypsum plaster with the addition of rosin and K12 is shown in Fig. 4. As expected, the thermal conductivity coefficient decreases with increased foaming agent. When the mass fraction of $\mathrm{K} 12$ was $0.1 \%$, the thermal conductivity coefficient was $0.18 \mathrm{~W} \mathrm{~m}^{-1} \mathrm{~K}^{-1}$.

In summary, $\mathrm{K} 12$ is more recommendable as foaming agent, when the mass fraction of $\mathrm{K} 12$ is around $0.1 \%$, the setting time and compressive strength meet the requirements of the standard. In the meanwhile, the thermal conductivity coefficient is $0.18 \mathrm{~W} \mathrm{~m}^{-1} \mathrm{~K}^{-1}$, which can be used as a thermal insulation material.

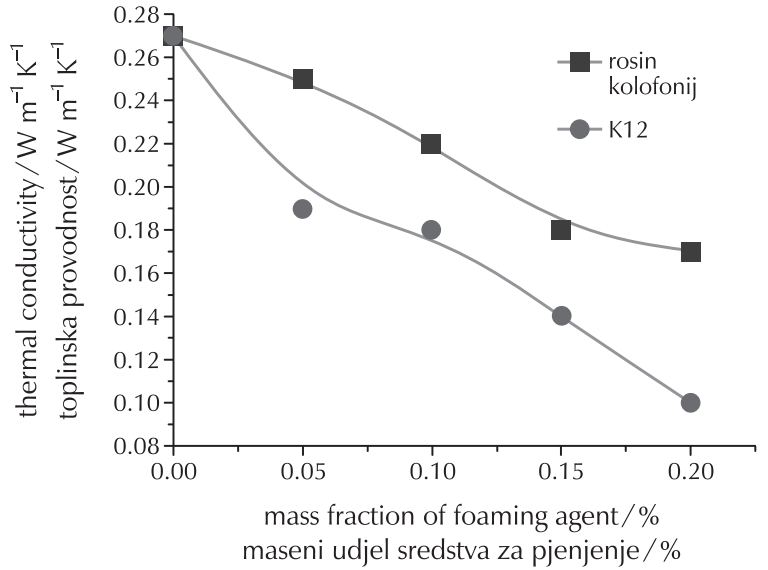

Fig. 4 - Thermal conductivity of gypsum plaster with the addition of rosin and $\mathrm{K} 12$

Slika 4 - Toplinska provodnost gipsane žbuke uz dodatak kolofonija i K12 


\subsection{Wall heat transfer coefficient}

Thermal insulation gypsum plaster is applied on the inner surface of walls, which can be used as the heat insulation layer and plaster layer of finish coating. The layer of conventional systems (from outer surface to inner surface) is $20 \mathrm{~mm}$ cement mortar, $200 \mathrm{~mm}$ conventional ACB, $15 \mathrm{~mm}$ cement mortar, $20 \mathrm{~mm}$ EPS, $5 \mathrm{~mm}$ cement mortar, and $5 \mathrm{~mm}$ putty. Combined with TIGP, a new type of wall insulation system is put forward. The layer of the new system (from outer surface to inner surface) is $5 \mathrm{~mm}$ thin-layer mortar, $5 \mathrm{~mm}$ waterproof interface agent, $250 \mathrm{~mm}$ lightweight ACB, and $5 \mathrm{~mm}$ TIGP. The new system can realize the objective of self-insulation.

The heat transfer coefficient of the new wall insulation system was tested compared with that of the conventional system. The test results of temperature in conventional and new wall insulation systems are shown in Fig. 5 and Fig. 6, respectively. As shown in the mentioned figures, the test results of temperature tend to be stable with increasing test time. The final test result of surface temperature on the hot side is higher than that on the cold side, which forms the condition of one-dimensional steady-state heat transfer.

Based on the one-dimensional heat transfer theory, the wall heat transfer coefficient can be defined as:

$$
K=\frac{Q}{A\left(T_{\text {ni }}-T_{\text {ne }}\right)}
$$

where $T_{\text {ni }}$ and $T_{\text {ne }}$ are the ambient temperatures of the hot side and the cold side, respectively; $Q$ represents total heat

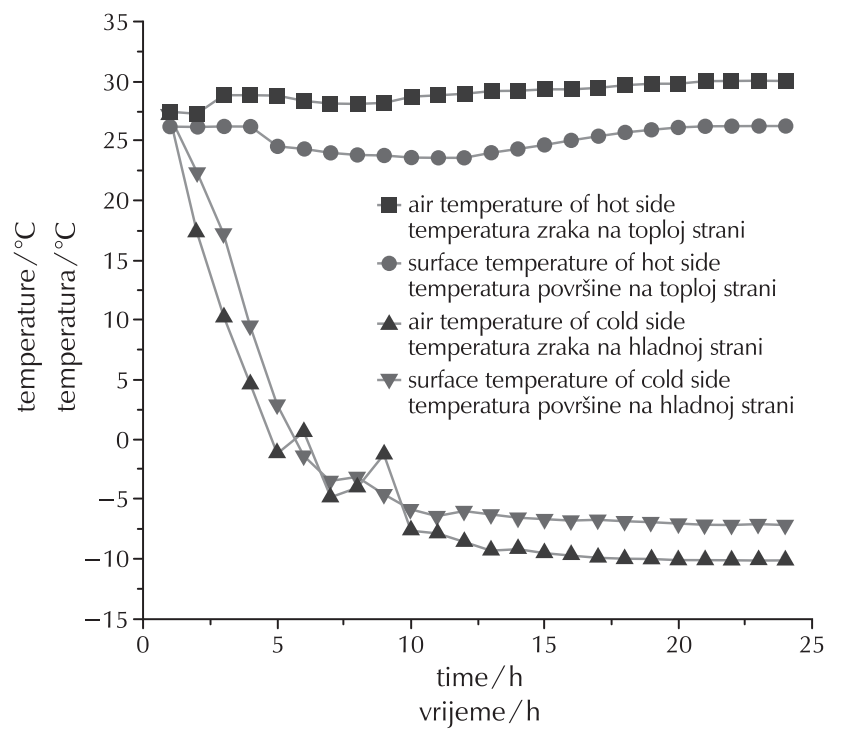

Fig. 5 - Test results of temperature of conventional wall insulation system

Slika 5 - Temperatura izolacijskog sustava s konvencionalnom izolacijom transfer capacity; $A$ represents the wall test area. In this test, total heat transfer capacity through conventional and new insulation systems were $53.98 \mathrm{~W}$ and $50.96 \mathrm{~W}$, respectively. The test area of wall was $1.44 \mathrm{~m}^{2}$.

The ambient temperatures of the hot side and the cold side are defined as:

$$
\begin{gathered}
T_{\text {ni }}=\frac{T_{\text {sai }} Q / A+\varepsilon h_{\mathrm{i}}\left(T_{\text {sai }}-T_{\text {mi }}\right) T_{\text {sis }}}{Q / A+\varepsilon h_{\mathrm{i}}\left(T_{\text {sai }}-T_{\text {mi }}\right)} \\
T_{\text {ne }}=\frac{T_{\text {sae }} Q / A+\varepsilon h_{\mathrm{e}}\left(T_{\text {sae }}-T_{\text {me }}\right) T_{\text {ses }}}{Q / A+\varepsilon h_{\mathrm{e}}\left(T_{\text {sae }}-T_{\text {me }}\right)}
\end{gathered}
$$

where $T_{\text {sai }}$ and $T_{\text {sae }}$ are the air temperatures of the hot side and cold side, respectively; $T_{\mathrm{mi}}$ and $T_{\mathrm{me}}$ are the mean radiant temperatures of the hot side and the cold side, respectively; $T_{\text {sis }}$ and $T_{\text {ses }}$ are the surface temperatures of the hot side and the cold side, respectively; $h_{\mathrm{i}}$ and $h_{\mathrm{e}}$ are the radiation heat transfer coefficients of the hot side and the cold side, respectively; $\varepsilon$ is the emissivity of inner surface, which in this test was a constant value of 0.85 .

According to the test results, we could calculate that the heat transfer coefficient of the conventional wall insulation system was $0.644 \mathrm{~W} \mathrm{~m}^{-1} \mathrm{~K}^{-1}$, while the heat transfer coefficient of the new system was $0.608 \mathrm{~W} \mathrm{~m}^{-1} \mathrm{~K}^{-1}$, which represents a reduction of $5.6 \%$ compared with that of the conventional system. The thermal performance of the new wall thermal insulation system had improved substantially.

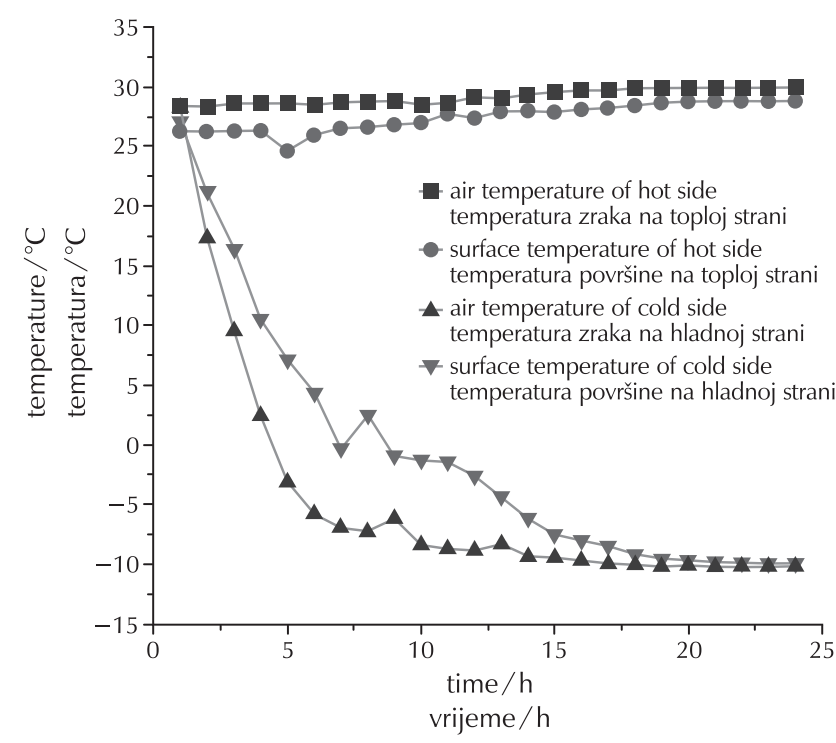

Fig. 6 - Test results of temperature of new wall insulation system

Slika 6 - Temperatura izolacijskog sustava s novim tipom izolacije 


\subsection{Energy-saving analysis}

Energy-saving analysis of a building was carried out to compare the energy-saving effects of the conventional thermal insulation system and the new system of a building. The analysis is based on an actual building. The building type was shear wall structure, located in a hot-summer and cold-winter zone in China. The design standard for residential buildings of low energy consumption (in accordance with the Chinese standard DB42/T 559-2013) ${ }^{18}$ was used in the energy-saving design. Calculation parameters were as follows: (1) indoor temperature: $26^{\circ} \mathrm{C}$ in summer; $18{ }^{\circ} \mathrm{C}$ in winter; (2) heating period: from December 1 to February 28; air-conditioning period: from June 15 to August 31; (3) outdoor weather: typical meteorological year; (4) air changes (ACH): once per hour; (5) energy efficiency ratio (EER): cooling 2.3; heating 1.9; (6) heat intensity: $4.3 \mathrm{~W} \mathrm{~m}^{-2}$.

After calculation, the energy-saving rate of the conventional thermal insulation system of the building was $65.21 \%$, while that of the new system could reach up to $66.99 \%$. The energy-saving rate of the new thermal insulation system with the new material obtained had increased by almost $2 \%$.

\section{Conclusion}

Thermal insulation gypsum plaster was prepared from flue gas desulphurization (FGD) gypsum. The obtained hemihydrate mixtures allowed the design of a new wall structure, which is more efficient as a thermal insulation system. Compared with the thermal performance of a conventional wall insulation system, the heat transfer coefficient of the new system had reduced by $5.6 \%$. Due to this reason, the energy-savings of the building with the new system had increased by almost $2 \%$, thus resulting in the building's low energy consumption.

\section{ACKNOWLEDGEMENTS}

The work is supported by the National Science and Technology Supporting Project (No. 2011BAJ03B03), the Wuhan Science and Technology Bureau Project (No. 2014070504020242), and the Wuhan Urban and Rural Construction Committee Project (No. 201443). Their support gave added value for the realization of this work that was done in collaboration.

\section{List of abbreviations and symbols Popis kratica i simbola}

\footnotetext{
ACB - aerated concrete block - plinobetonski blok

$\mathrm{ACH}-$ air changes

- izmjena zraka

EER - energy efficiency ratio

- omjer energijske učinkovitosti
}

EPS - expanded polystyrene

- ekspandirani polistiren

F10 - polycarboxylate-based water-reducing admixture

- polikarboksilatni plastifikator

FGD - flue gas desulphurization

- odsumporavanje dimnih plinova

HPMC - ether-based water-retention admixture

- eterski aditiv za zadržavanje vode

K12 - lauryl sodium sulphate

- natrijev lauril-sulfat

SC - protein-based retarder

- proteinski usporivač vezivanja

TIGP - thermal insulation gypsum plaster

- toplinskoizolacijska gipsana žbuka

A $\quad$ - wall test area, $\mathrm{m}^{2}$

- ploština ispitivanog zida, $\mathrm{m}^{2}$

$h_{\mathrm{i}}, h_{\mathrm{e}} \quad-$ hot/cold side radiation heat transfer coefficient, $\mathrm{W} \mathrm{m}^{-2} \mathrm{~K}^{-1}$

- koeficijent radijacijskog prijenosa topline na vrućoj/ hladnoj strani, $\mathrm{W} \mathrm{m}^{-2} \mathrm{~K}^{-1}$

$K \quad-$ heat transfer coefficient, $\mathrm{W} \mathrm{m}^{-2} \mathrm{~K}^{-1}$

- koeficijent prijenosa topline, $\mathrm{W} \mathrm{m}^{-2} \mathrm{~K}^{-1}$

Q - heat, W

- toplina, W

$T_{\text {mir }}, T_{\text {me }}-$ hot/cold side mean radiant temperature, $\mathrm{K}$

- srednja radijacijska temperatura na na vrućoj/hladnoj strani, K

$T_{\text {ni, }} T_{\text {ne }}-$ hot/cold side ambient temperature, $\mathrm{K}$

- temperatura okoline na toploj/hladnoj strani, K

$T_{\text {sai, }} T_{\text {sae }}-$ hot/cold side air temperature, $\mathrm{K}$

- temperatura zraka na toploj/hladnoj strani, $\mathrm{K}$

$T_{\text {sis, }} T_{\text {ses }}-$ hot/cold side surface temperature, $\mathrm{K}$

- temperatura površine na toploj/hladnoj strani, $\mathrm{K}$

w $\quad-$ mass fraction, $\%$

- maseni udjel, \%

- emissivity

- izračivost

\section{References \\ Literatura}

1. M. Singh, M. Garg, Retarding action of various chemicals on setting and hardening characteristics of gypsum plaster at different pH, Cement Concrete Res. 27 (1997) 947-950, doi: http://dx.doi.org/10.1016/S0008-8846(97)00045-8.

2. E. Tazawa, Effect of self-stress on flexural strength of gypsum-polymer composites, Adv. Cem. Based Mater. 7 (1998) 1-7, doi: http://dx.doi.org/10.1016/S1065-7355(97)000102.

3. G. Lucas, Capillary conductivity and body formation in moulds of special plaster-results from laboratory and practice, Interceram 46 (1997) 419-424.

4. J. R. Mehaffey, P. Cuerrier, G. Carisse, A model for predicting heat transfer through gypsum board/wood-stud walls exposed to fire, Fire Mater. 8 (1994) 297-305, doi: http:// dx.doi.org/10.1002/fam.810180505.

5. M. A. Sultan, Model for predicting heat transfer through non-insulated unloaded steel-stud gypsum board wall assemblies exposed to fire, Fire Technol. 32 (1996) 239-259, doi: http://dx.doi.org/10.1007/BF01040217.

6. P. Tesarek, J. Drchalova, J. Kolisko, P. Rovnanikova, R. Cerny, 
Flue gas desulfurization gypsum: Study of basic mechanical, hydric and thermal properties, Constr. Build. Mater. 21 (2007) 1500-1507, doi: http://dx.doi.org/10.1016/j.conbuildmat.2006.05.009

7. M. Lanzon, P. A. Garcia-Ruiz, Effect of citric acid on setting inhibition and mechanical properties of gypsum building plasters, Constr. Build. Mater. 28 (2012) 506-511, doi: http:// dx.doi.org/10.1016/j.conbuildmat.2011.06.072.

8. S. K. Hamdona, O. A. Al Hadad, Influence of additives on the precipitation of gypsum in sodium chloride solutions, Desalination 228 (2008) 277-286, doi: http://dx.doi. org/10.1016/j.desal.2007.11.008.

9. R. X. Magallanes-Rivera, C. A. Juarez-Alvarado, P. Valdez, J. M. Mendoza-Rangel, Modified gypsum compounds: An ecological-economical choice to improve traditional plasters, Constr. Build. Mater. 37 (2012) 591-596, doi: http://dx.doi. org/10.1016/j.conbuildmat.2012.07.054.

10. Y. Matsushita, S. Yasuda, Preparation and evaluation of lignosulfonates as a dispersant for gypsum paste from acid hydrolysis lignin, Bioresource Technol. 96 (2005) 465-470, doi: http://dx.doi.org/10.1016/j.biortech.2004.05.023.

11. X. Wang, L.-S. Yang, X.-F. Zhu, J.-K. Yang, Preparation of calcium sulfate whiskers from FGD gypsum via hydrothermal crystallization in the $\mathrm{H}_{2} \mathrm{SO}_{4}-\mathrm{NaCl}-\mathrm{H}_{2} \mathrm{O}$ system, Particuolo- gy 17 (2014) 42-48, doi: http://dx.doi.org/10.1016/j.partic.2013.12.001

12. J. Zhou, C. Liu, Z. Shu, D.-X. Yu, Q.-Y. Zhang, T.-T. Li, Q. Xue, Preparation of specific gypsum with advanced hardness and bending strength by a novel in-situ loading-hydration process, Cement Concrete Res. 67 (2015) 179-183, doi: http:// dx.doi.org/10.1016/j.cemconres.2014.09.004.

13. S. Gutiérrez-González, M. M. Alonso, J. Gadea, A. Rodríguez, $\checkmark$. Calderón, Rheological behaviour of gypsum plaster pastes with polyamide powder wastes, Constr. Build. Mater. 38 (2013) 407-412, doi: http://dx.doi.org/10.1016/j.conbuildmat.2012.08.034.

14. Z. Z. Zhi, Preparation and properties of functional desulfurization gypsum based plaster, Wuhan: Wuhan University of Technology. 6 (2014) 8-10.

15. GB/T 17669.4-1999, Gypsum plasters-Determination of physical properties of pure paste.

16. JC/T 517-2004, Gypsum plaster.

17. GB/T 13475-2008, Thermal insulation-Determination of steady-state thermal transmission properties-Calibrated and guard hot box.

18. DB42/T 559-2013, Design standard for residential buildings of low energy consumption.

\title{
SAŽETAK
}

\section{Priprava toplinskoizolacijske žbuke s FGD-gipsom}

\author{
Yi-Chao Zhang, ${ }^{a}$ Shao-Bin Dai, Jun Huang, ${ }^{{ }^{*}}$ Sheng-Gang Duan ${ }^{\mathrm{a}}$ i Zhen-Zhen Zhi ${ }^{\mathrm{b}}$
}

Toplinskoizolacijska gipsana žbuka izrađena je od gipsa nastalog odsumporavanjem dimnog plina (FGD). Uz maseni udjel sredstva za pjenjenje (K12) 0,1 \% toplinska provodnost iznosi $0,18 \mathrm{~W} \mathrm{~m}^{-1} \mathrm{~K}^{-1}$ pa se materijal može upotrijebiti za toplinsku izolaciju. Zbuka i sredstvo za pjenjenje uključeni su u novi tip zidne toplinske izolacije. Koeficijent prijenosa topline novog izolacijskog sustava određen je eksperimentalno i iznosi $0,608 \mathrm{~W} \mathrm{~m}^{-2} \mathrm{~K}^{-1}$. Na temelju analize zaključeno je da se s novim sustavom ušteda energije u zgradi može popeti do $66,99 \%$. Novi materijal može imati velik utjecaj na energijsku učinkovitost zgrade.

\section{Ključne riječi}

Gips nastao odsumporavanjem dimnog plina, toplinska izolacija, koeficijent prijenosa topline, sredstvo za pjenjenje, energijska (energetska) učinkovitost

\footnotetext{
a School of Civil Engineering and Architecture, Wuhan University of Technology, Wuhan 430070 , Kina

${ }^{b}$ School of Materials Science and Engineering, Wuhan University of Technology, Wuhan 430 070, Kina
}

Stručni rad

Prispjelo 17. veljače 2016. Prihvaćeno 29. travnja 2016. 